\section{Short communication report \\ MICROORGANISMS ASSOCIATED WITH THE URINOGENITAL SYSTEM OF VESICO VAGINAL FISTULA (VVF) PATIENTS IN NORTH WESTERN NIGERIA.}

\author{
*A. YABAYA \& B. AUTA \\ Department of Microbiology \\ Kaduna State University \\ Kaduna Nigeria \\ *(Corresponding author) \\ amosyabaya2002@yahoo.com
}

Vesico Vaginal Fistula (VVF) is a devastating childbirth injury that results in the abnormal fusion between the urinary bladder and the vagina. It is the commonest type of gynecological abnormality (fistula) in the developing countries, which Andrew (1999) described as an old menace to mankind and a constant source of misery to the affected patient. Recent estimates suggest that 3 million women live with fistula, mainly in subSaharan Africa and South Asia (Wall 2006).

The commonest cause of VVF is a prolonged and obstructed labour in pregnant women during delivery. Other causes of the problem include cephalopelvic disproportion, a situation where the head of the baby is too big to pass through the birth canal as well as malpresentation and malposition of the baby, which is an abnormal position maintained by the baby at the time of labour which leads to difficulty of the head to come out first. It is common in communities where teenagers are given out in marriage early in life. VVF is characterized by uncontrolled dripping of urine down the legs, resulting in the constant wetting of the clothes and production of an irritating stench. Available evidence from the United States and the United Kingdom revealed that $70 \%$ of fistulae are sequelae of pelvic surgery (Hadley 2002), unlike in Africa where about $90 \%$ of fistulae are caused by obstructed or prolonged labor (Danso et al. 1996; Hadley 2002)

In Nigeria, about $80 \%$ of VVF cases are due to unrelieved obstructed labour during childbirth which is directly related to the custom of early marriage (Ojanuga \& Ekwempu 1999). In view of the fact that VVF is associated with urogenital infections and ammonia dermatitis that often result to severe psychosocial trauma, this investigation was made aimed at studying the micro organisms in patients presenting with urogenital fistulae in VVF units at Sokoto, Gusau and Birnin Kebbi, north-western Nigeria.

High Vaginal Swabs

A total of 100 high vaginal swabs (HVS) were collected from patients at the VVF centers in Sokoto, Gusau and Birnin Kebbi, Nigeria. Each swab was transferred into $10 \mathrm{ml}$ of sterile distilled water and serially diluted to $10^{-4}$ and the diluents inoculated onto sarbouraud's dextrose agar.

Urine samples

100 samples of urine were collected using sterile syringes from the ascending tube before reaching the urine bag. The urine was dispensed in universal bottles, covered and spine at 10000 rpm after which the supernatant was decanted and the sediment inoculated on Chocolate and McConkey agar media and incubated at $37^{\circ} \mathrm{C}$ for $24 \mathrm{hr}$.

\section{Analysis}

The axenic cultures were analysed using microscopy and biochemical analysis. Indole and $\mathrm{H}_{2} \mathrm{~S}$ production were carried out to identify the microorganisms according to the methods of Barrow \& Feltham (1993). Questionnaires were administered to all the 100 patients and analysed with respect to age group and the assistance they received during delivery.

Most of the microorganisms that were isolated belong to the Enterobacteriacaea family. A total of eight were isolated made up of Escherichia coli (Migula 1895) Caslellani \& Chalmens 1919 from 99 patients, Enterobacter cloacae (Jordan 1890) Hormaeche \& Edwards 1960 in 81 patients followed by Corynebacterium diphtheriae (Kruse 1886) Lehmann \& Neumann 1896 and Proteus vulgaris Hauser 1885 that were isolated in 44 and 4 patients respectively. Lowest infections were due to Pseudomonas aeruginosa (Schroeter 1872) Migula 1900 encountered in only 14 patients (Table 1).

\section{TABLE 1. OCCURRENCE OF MICROORGANISMS IN PATIENTS WITH VVF.}

\begin{tabular}{ll}
\hline Microorganism & Frequency (\%) \\
\hline Candida albicans & 32 \\
\hline Citrobacter amalonaticus & 23 \\
\hline Corynebacteria diphtheriae & 44 \\
\hline Enterobacter cloacae & 81 \\
\hline Escherichia coli & 99 \\
\hline Klebsiella pneumoniae & 22 \\
\hline Proteus vulgaris & 40 \\
\hline Pseudomonas aeruginosa & 14 \\
\hline
\end{tabular}

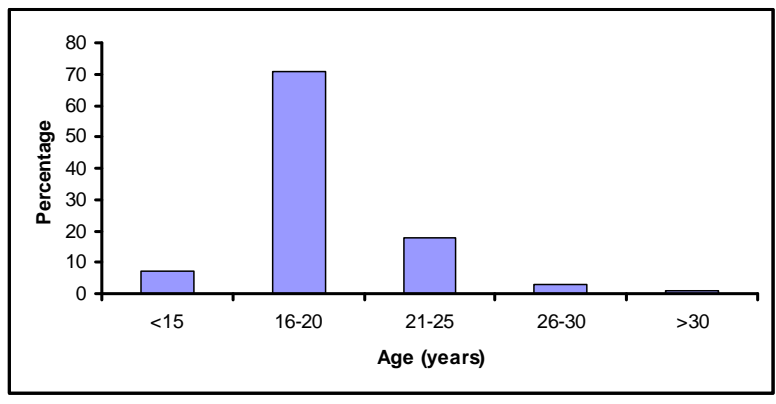

FIG 1. INCIDENCE OF VVF WITH AGE AT FIRST PREGNANCY IN NORTH WEST NIGERIA

The growth of the bacterial colonies is presented in Table 2 while the results of the questionnaire response summarizing the 
different types of influence contributing to VVF menace is presented in Table 3. Fig. 1 presents the distribution of VVF according to the age of the patients.

\section{TABLE 2: MEAN COLONY FORMING UNITS OF MICROORGANISMS ISOLATED FROM VVF PATIENTS}

\begin{tabular}{ll}
\hline Microorganism & $\begin{array}{l}\text { Colony forming } \\
\text { units/ml }\end{array}$ \\
\hline Candida albicans & $12 \times 10^{4}$ \\
\hline Citrobacter amalonaticus & $15 \times 10^{4}$ \\
\hline Corynebacteria diphtheriae & $49 \times 10^{4}$ \\
\hline Enterobacter cloacae & $18 \times 10^{4}$ \\
\hline Escherichia coli & $36 \times 10^{4}$ \\
\hline Klebsiella pneumoniae & $45 \times 10^{3}$ \\
\hline Proteus vulgaris & $21 \times 10^{4}$ \\
\hline Pseudomonas aeruginosa & $14 \times 10^{4}$ \\
\hline
\end{tabular}

\section{TABLE 3 TYPE OF ASSISTANCE THAT CONTRIBUTED TO VVF DURING DELIVERY}

\begin{tabular}{ll}
\hline Assistance rendered & Percentage \\
\hline Patient's mother & 17.0 \\
\hline Mother-in-law & 35.0 \\
\hline Traditional Birth Attendant & 3.0 \\
\hline Trained worker & 0.0 \\
\hline Self delivery & 16.0 \\
\hline Friend & 12.0 \\
\hline Clinic & 9.0 \\
\hline Husband & 3.0 \\
\hline Other & 5.0 \\
\hline TOTAL & 100.0 \\
\hline
\end{tabular}

The results from this study indicate that VVF patients from the present study areas are infected with various species of microorganisms, majority of which belong to the same group earlier reported for hospitalized patients (Barrow \& Feltham 1993), further reaffirming the results of Kunin et al. (1980), Agba et al. (2002) and Dalela et al. (2003) that VVF patients are prone to microbial colonization. Ghatak (1992) conducted a retrospective study in Sokoto and observed high urinary tract infection of $26 \%$, only next to pelvic abnormality. It was not possible to comment on the situation in the different areas where the samples were drawn because of the small sample size. However, several reports (Ojanuga 1991; Ojanuga \& Ekwempu 1999; Wall et al. 2004) indicated that it is a big but neglected problem in northern Nigeria.

The results further confirmed that majority of the patients are young and inexperienced, aged between $16-20 \mathrm{yr}$ old. The high microbial colonization of the patients could be attributed to their low level of personal hygiene arising from their inexperience to keep themselves clean. The mean age at which girls are married out in the area is $13 \mathrm{yr}$ (Ibrahim et al. 2000). Another contributing factor to the colonization could be the non-removal of the catheter (Warren 2001)

The influence of mother-in-law as a contributing factor in VVF complication is high in our study. This could be the result of absence of alternative medical health care facility particularly in the rural areas. Ibrahim et al. (2000) studied VVF patients in Sokoto, the same region where this study was conducted and reported that $77 \%$ did not receive antenatal care. The same study reported that only $6 \%$ of the patients could read or write in English but more than $80 \%$ had Quranic education, indicating that the control of VVF in the area is not possible without integrating maternal and child health $(\mathrm{MCH})$ education in the curriculum of Quranic schools. To be sure of success, special health education programs on maternal health should also be extended to the religious leaders, a suggestion earlier made by Ibrahim et al. (2000), in addition to advocacy for free antenatal care and delivery services at the primary and secondary levels. More personnel should be trained to bring $\mathrm{MCH}$ services closer to the grassroots. Above all, special attention should be given to the socio-cultural barriers to good reproductive health among women by legislating against the practice of very early pregnancy and childbirth in very young women which is a direct consequence of early marriage. Of the different likely causes of VVF, the influence of orthodox practioners in the complication was low, confirming the observation earlier made by Ghatak (1992) in the area.

Besides the severe social consequences from the irritating stench of urine that often result in ostracizing the affected women from the community, Edwards (1994) reported that overlooking the presence of pathogenic microorganism in VVF patients may lead to further complications such as pyelonephritis and pelvic inflammation.

\section{REFERENCES}

Agba, M. I. Chukwukere, L. C.; Chukwukere, S. C.; Nwobu, G. O. \& Okpala, H. O. 2002. Bacterial colonization of urinary tract of pregnant women attending antenatal clinic in Vom. Nigerian Journal of Biotechnology 13(1): 73-77.

Andrew, M. H. 1999. Vesico Vaginal Fistula associated with urinary prolapsed. British Journal of Obstetric and Gynecology 106:1227-1228

Barrow, G.I \& Feltham, R. K. A. 1993. Bacterial characters and characterization. Cowan and Steel's Manual for the Identification of Medical Bacteria (3rd Ed) Cambridge University Press.

Dalela, D.; Goel, A.; Shakhwar, S. N. \& Singh, K. M. 2003. Vesical calculi with unrepaired vesicovaginal fistula: a clinical appraisal of an uncommon association. Journal of Urology 170,6(1):2206-8.

Danso, K. A.; Martey, J. O.; Wall, L. L. \& Elkins, T. E. 1996). The epidemiology of genitourinary fistulae in Kumasi, Ghana 1977-1992. International Urogynecology Journal of Pelvic Floor Dysfunction 7(3):117-20. 
Edward, I. E. 1994. Nosocomial Diseases. Fundamentals of Microbiology (4th Edition). The Benjamin Cunnings publishing company, California.

Ghatak, D. P. 1992. A study of urinary fistulae in Sokoto, Nigeria. Journal of Indian Medical Association 90(11):285-7

Hadley, H. R. 2002. Vesicovaginal fistula. Current Urology Report October;3(5):401-7.

Ibrahim, T.; Sadiq, A. U. \& Daniel, S. O. 2000. Characteristics of VVF patients as seen at the specialist hospital Sokoto, Nigeria. West African Journal of Medicine 19(1):59-63.

Kunin, C.M.; Polyak, F. \& Fostel, E. 1980. Preuretheral bacterial flora prolong Intermittent colonization of $E$. coli. Journal of Medical Association 243: 134-139.

Ojanuga, D. 1991. Preventing birth injury among women in Africa: case studies in northern Nigeria. American Journal of Orthpsychiatry Oct;61(4):533-9.
Ojanuga, O. D. \& Ekwempu, C. C. 1999. An investigation of sociomedical risk factors associated with vaginal fistula in northern Nigeria. Women Health. 28(3):103-16

Wall, L.L.; Karshima, J. A.; Kirschner, C. \& Arrowsmith, S. D. 2004. The obstetric vesicovaginal fistula: characteristics of 899 patients from Jos, Nigeria. American Journal of Obstetric Gynecology. April 190(4):1011-9

Wall, L. L. 2006. Obstetric vesicovaginal fistula as an international public-health problem. Lancet. September 30;368(9542):1201-9

Warren, J. W. 2001. Catheter-associated urinary tract infections. International Journal of Antimicrobial Agents. 17(4):299-303. 